Article

\title{
Catalytic Oxidation of Phenol and 2,4-Dichlorophenol by Using Horseradish Peroxidase Immobilized on Graphene Oxide/ $\mathrm{Fe}_{3} \mathrm{O}_{4}$
}

\author{
Qing Chang, Jia Huang, Yaobin Ding and Heqing Tang * \\ College of Resources and Environmental Science, South Central University for Nationalities, \\ Wuhan 430074, China; changqinghust@163.com (Q.C.); jjhhhust@163.com (J.H.); dyaobin@126.com (Y.D.) \\ * Correspondence: tangheqing@mail.scuec.edu.cn; Tel./Fax: +86-27-6784-3918 \\ Academic Editor: Roberto Fernandez-Lafuente \\ Received: 12 April 2016; Accepted: 3 August 2016; Published: 10 August 2016
}

\begin{abstract}
Graphene oxide $/ \mathrm{Fe}_{3} \mathrm{O}_{4}\left(\mathrm{GO} / \mathrm{Fe}_{3} \mathrm{O}_{4}\right)$ nanoparticles were synthesized by an ultrasonic-assisted reverse co-precipitation method, and then horseradish peroxidase (HRP) was covalently immobilized onto $\mathrm{GO} / \mathrm{Fe}_{3} \mathrm{O}_{4}$ with 1-ethyl-3-(3-dimethyaminopropyl)carbodiimide (EDC) as a cross-linking agent. In order to enhance the phenol removal efficiency and prevent the inactivation of the enzyme, the polyethylene glycol with highly hydrophilicity was added in this reaction, because the adsorption capacity for the polymer by degradation was stronger than the HRP. The results showed that the immobilized enzyme removed over $95 \%$ of phenol from aqueous solution. The catalytic condition was extensively optimized among the range of $\mathrm{pH}$, mass ratio of $\mathrm{PEG} /$ phenol as well as initial concentration of immobilized enzyme and $\mathrm{H}_{2} \mathrm{O}_{2}$. The $\mathrm{HRP}$ immobilized on $\mathrm{GO} / \mathrm{Fe}_{3} \mathrm{O}_{4}$ composite could be easily separated under a magnetic field from the reaction solution and reused.
\end{abstract}

Keywords: graphene oxide; magnetite; phenol; immobilized enzyme; catalytic oxidation

\section{Introduction}

A great amount of industrial wastewaters containing phenolic compounds are generated from coal conversion, resins and plastics processing, coke combustion, and so on. Many phenolic compounds are a potential danger to human health and suspected to be carcinogen [1,2]. One treatment approach is based on the oxidation of phenolic pollutant by natural enzymes [3]. This treatment has many advantages compared with other biological or chemical/physical methods. It is easier than microorganism manipulation for handling and storage of isolated enzymes. Moreover, the specificity of enzymes is much higher with respect to other conventional catalysts.

Horseradish peroxidase (HRP) is a classic heme enzyme containing a ferric protoporphyrin IX prosthetic group. In the presence of hydrogen peroxide $\left(\mathrm{H}_{2} \mathrm{O}_{2}\right), \mathrm{HRP}$ catalyzed the oxidation of phenols to form phenoxy radicals [4]. The free radical products spontaneously formed insoluble high molecular weight polymers, which could be removed from solution by filtration or sedimentation [5]. However, during the enzymatic treatment, the generated phenoxy radicals may interact with the active center of the enzyme, leading to shortened catalytic lifetime of the enzyme [6]. In addition, the generated polymers may entrap HRP, decreasing its catalytic ability. In order to overcome the problem of the inactivation of the enzyme, it was reported that the enzyme lifetime was significantly improved by using polyethylene glycol (PEG) or gelatin with high hydrophilicity, which have a greater affinity than HRP for the hydroxyl groups on the growing polymers [7,8]. Another strategy for overcoming the problem of the inactivation of the enzyme was to immobilize enzymes.

It is demonstrated that enzyme immobilization can endow enzymes with some additional advantageous properties [9]. Compared with free enzyme, immobilized enzymes dispersed on the 
support surface will suffer from less aggregation, which is another inactivation source [10]. A proper enzyme immobilization may produce a strong rigidification of the enzyme structure, especially if a very intense multipoint covalent attachment of enzymes on the support via short spacer arms is achieved [11]. Because all enzyme residues involved in the enzyme immobilization process should maintain their relative positions during any conformational change induced by more drastic conditions, it reduced any conformational change involved in enzyme inactivation and significantly improved the enzyme stability [12,13]. Besides the immobilized enzymes exhibit higher selectiveness and specificity [14]. Nonetheless, enzymes can be denatured and lose their activity simply when solubilized in the immobilization medium and during the immobilization procedure. The immobilization of enzymes may block the active centers and promote diffusion problems [10]. It is also reported that the diffusional limitation (e.g., the generation of gradients of $\mathrm{pH}$ ) in the porous support immobilized with very active enzyme might provide a profitable tool to improve the operational parameters of enzymes [15]. It is also suggested that the immobilized enzymes can be used repeatedly or continuously in a variety of reactors for the efficient recovery of costly enzymes, and be easily separated from reaction systems for reuse, which make the work-up simple and the protein of the final product uncontaminated [16].

Nanoparticles are considered to be excellent supports for enzyme immobilization because of their minimized diffusional limitations, high specific surface area and high enzyme loading capability, mechanical stability, which are interesting and important features for the immobilization process [17]. Nevertheless, the purity of the enzyme sample only impairs the volumetric activity when using non-porous nanoparticle supports [10]. Moreover, the recovery by centrifugation and filtration of these nanoparticles is very difficult. Magnetic supports show the obvious feature of being ferromagnetic, which allows recovery of the immobilized enzyme preparation from a reactor by simply applying a magnetic field to the slurry, without the need of tedious decantation, centrifugation, or filtration procedures [18]. $\mathrm{Fe}_{3} \mathrm{O}_{4}$ magnetic nanoparticles (MNPs) are known to be biocompatible, display no hemolytic activity and genotoxicity with superparamagnetic properties and have been utilized in various fields [19]. It was found that $\mathrm{Fe}_{3} \mathrm{O}_{4} \mathrm{MNPs}$ have the peroxidase-like property and could activate $\mathrm{H}_{2} \mathrm{O}_{2}$ to degrade organic pollutant [20]. Furthermore, $\mathrm{Fe}_{3} \mathrm{O}_{4} \mathrm{MNPs}$ can feasibly combine with easily modifiable materials, and modify inherently their surface with functional groups to link interested enzymes. Graphene oxide (GO), a derivation of graphene, having a large specific surface area and a range of reactive oxygen functional groups on the surface, not only renders it a good candidate for supporting metal or metal oxide particles, but also provides an ideal substrate for enzyme immobilization [21]. In this study, $\mathrm{GO} / \mathrm{Fe}_{3} \mathrm{O}_{4} \mathrm{MNPs}$ were synthesized with an ultrasonic-assisted reverse co-precipitation method, and then $\mathrm{HRP}$ was covalently immobilized onto the $\mathrm{GO} / \mathrm{Fe}_{3} \mathrm{O}_{4}$ as an enzyme carrier. This composite system could highly efficiently catalyze the reduction of $\mathrm{H}_{2} \mathrm{O}_{2}$ to remove phenol and 2,4-dichlorophenol (2,4-DCP).

\section{Results and Discussion}

\subsection{Characterization of Materials}

The magnetization curve of $\mathrm{GO} / \mathrm{Fe}_{3} \mathrm{O}_{4}$ nanoparticles was measured at room temperature, as shown in Figure 1a, which demonstrated that the $\mathrm{GO} / \mathrm{Fe}_{3} \mathrm{O}_{4}$ exhibited negligible coercivity $(1.17 \mathrm{Oe})$ and remanence $\left(73.06 \times 10^{-3} \mathrm{emu} / \mathrm{g}\right)$, being typical of superparamagnetic materials. The specific saturation magnetization, $M_{\mathrm{s}}$ of the sample, was $25.96 \mathrm{emu} / \mathrm{g}$. This value was smaller than the reported value of bulk $\mathrm{Fe}_{3} \mathrm{O}_{4}$ of $68.80 \mathrm{emu} \cdot \mathrm{g}^{-1}$ [19]. $\mathrm{Fe}_{3} \mathrm{O}_{4}$ was estimated as $37.7 \mathrm{wt} \%$ calculated from the content of $\mathrm{GO} / \mathrm{Fe}_{3} \mathrm{O}_{4}$. X-ray powder diffraction was used to identify the produced powders as shown in Figure 1b. The broad small characteristic peak of GO around $24^{\circ}$ can be observed, which was attributed to $\mathrm{C}(002)$ reflection of graphite oxide based on the short-range order in stacked sheets [22]. The diffraction peaks at $11.0^{\circ}$ was assigned to the characteristic GO (001) crystal. The characteristic diffraction peaks $(2 \theta)$ of $\mathrm{GO} / \mathrm{Fe}_{3} \mathrm{O}_{4}$ at 30.4, 35.6, 43.3, 53.0, 57.1, and $62.8^{\circ}$ were ascribed to the 
(220), (311), (400), (422), (511) and (440) planes of $\mathrm{Fe}_{3} \mathrm{O}_{4}$, being similar to the previously reported data $[23,24]$. For magnetic particles with bound HRP, the same six characteristic peaks were observed. This suggested that the binding process did not result in the phase change of $\mathrm{GO} / \mathrm{Fe}_{3} \mathrm{O}_{4}$. As a result, the magnetic particles could preserve their magnetic properties during the separation process, which was suitable for application in bioseparation. A TEM image of the prepared immobilized enzyme indicated GO sheets uniformly decorated with nanoparticles with a narrow size distribution, as shown in Figure 1c. The morphology is similar to $\mathrm{GO} / \mathrm{Fe}_{3} \mathrm{O}_{4}$ nanoparticles synthesized in our previous work [21].
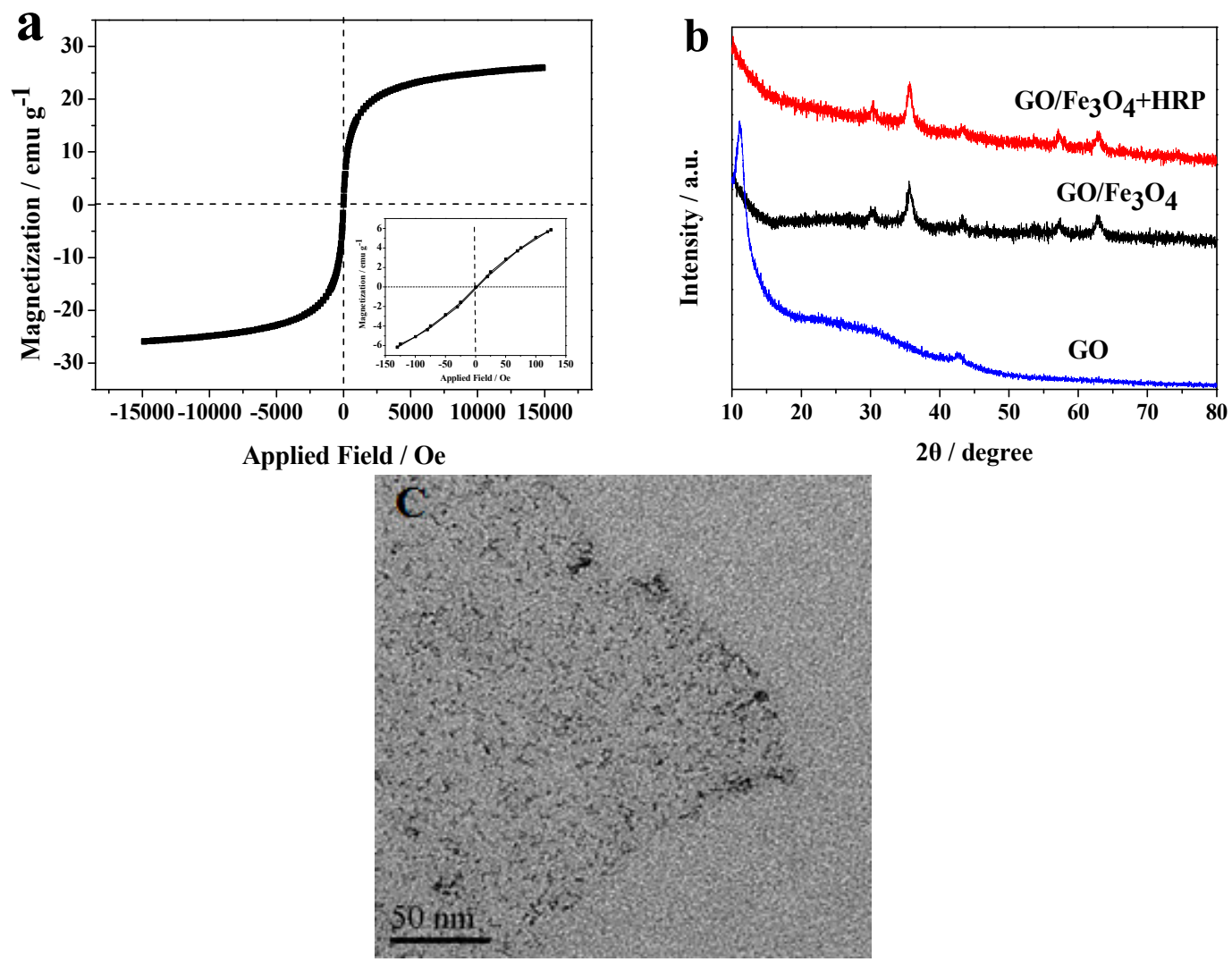

Figure 1. (a) Magnetization curve of $\mathrm{GO} / \mathrm{Fe}_{3} \mathrm{O}_{4}$; (b) The X-ray diffraction patterns of $\mathrm{GO}, \mathrm{GO} / \mathrm{Fe}_{3} \mathrm{O}_{4}$ and $\mathrm{GO} / \mathrm{Fe}_{3} \mathrm{O}_{4}+\mathrm{HRP}$; (c) TEM image of $\mathrm{GO} / \mathrm{Fe}_{3} \mathrm{O}_{4}+\mathrm{HRP}$.

\subsection{Reaction System and Effect of PEG}

The procedures for the synthesis of $\mathrm{GO} / \mathrm{Fe}_{3} \mathrm{O}_{4}$ particles and the immobilization of HRP onto $\mathrm{GO} / \mathrm{Fe}_{3} \mathrm{O}_{4}$ with EDC as a cross-linking agent are illustrated in Scheme 1. The amount of immobilized enzyme was about $5.3 \mathrm{mg} / \mathrm{g}$ on the magnetic $\mathrm{GO} / \mathrm{Fe}_{3} \mathrm{O}_{4}$ nanoparticles. The initial HRP specific activity was $128 \mathrm{U} / \mathrm{mg}$ and the measured activity of the immobilized HRP was about $440 \mathrm{U} / \mathrm{g}$, while retained about $65 \%$ of initial HRP activity.

As it was known, inactivation is due to the adsorption of enzyme onto the polymers formed during the reaction [8]. In order to reduce the amount of the enzyme, several researchers have suggested that highly hydrophilic additives such as PEG and gelatin can be used to protect the enzyme from inactivation during phenol removal. In Figure $2 a$, when there is an absence of PEG, the phenol removal efficiency is only about $9 \%$. Within a 3-h reaction period, the removal of phenol achieved $95 \%$ in the $\mathrm{GO} / \mathrm{Fe}_{3} \mathrm{O}_{4}$-HRP system, being much greater than the $\mathrm{GO} / \mathrm{Fe}_{3} \mathrm{O}_{4}$ and $\mathrm{GO} / \mathrm{Fe}_{3} \mathrm{O}_{4}+\mathrm{PEG}$ system (almost no reduction). Correspondingly, in Figure 2c, about $78 \%$ of the total organic carbon (TOC) was found to be removed. As we all know, $\mathrm{Fe}_{3} \mathrm{O}_{4}$ and $\mathrm{GO}$ are proved that possess enzyme 
mimetic activity $[20,21]$. However, the phenol was not removed, because the amount of the $\mathrm{H}_{2} \mathrm{O}_{2}$ was fairly small compared to other reports [20].

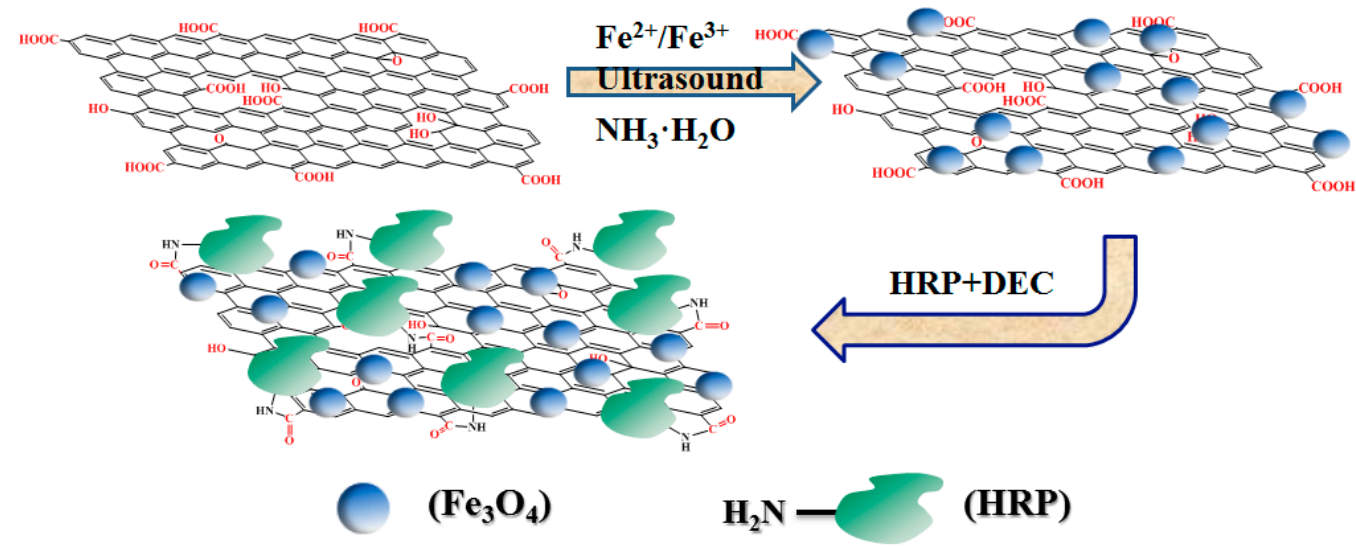

Scheme 1. Schematic illustration of $\mathrm{HRP}$ immobilized on $\mathrm{GO} / \mathrm{Fe}_{3} \mathrm{O}_{4}$ by $\mathrm{EDC}$.
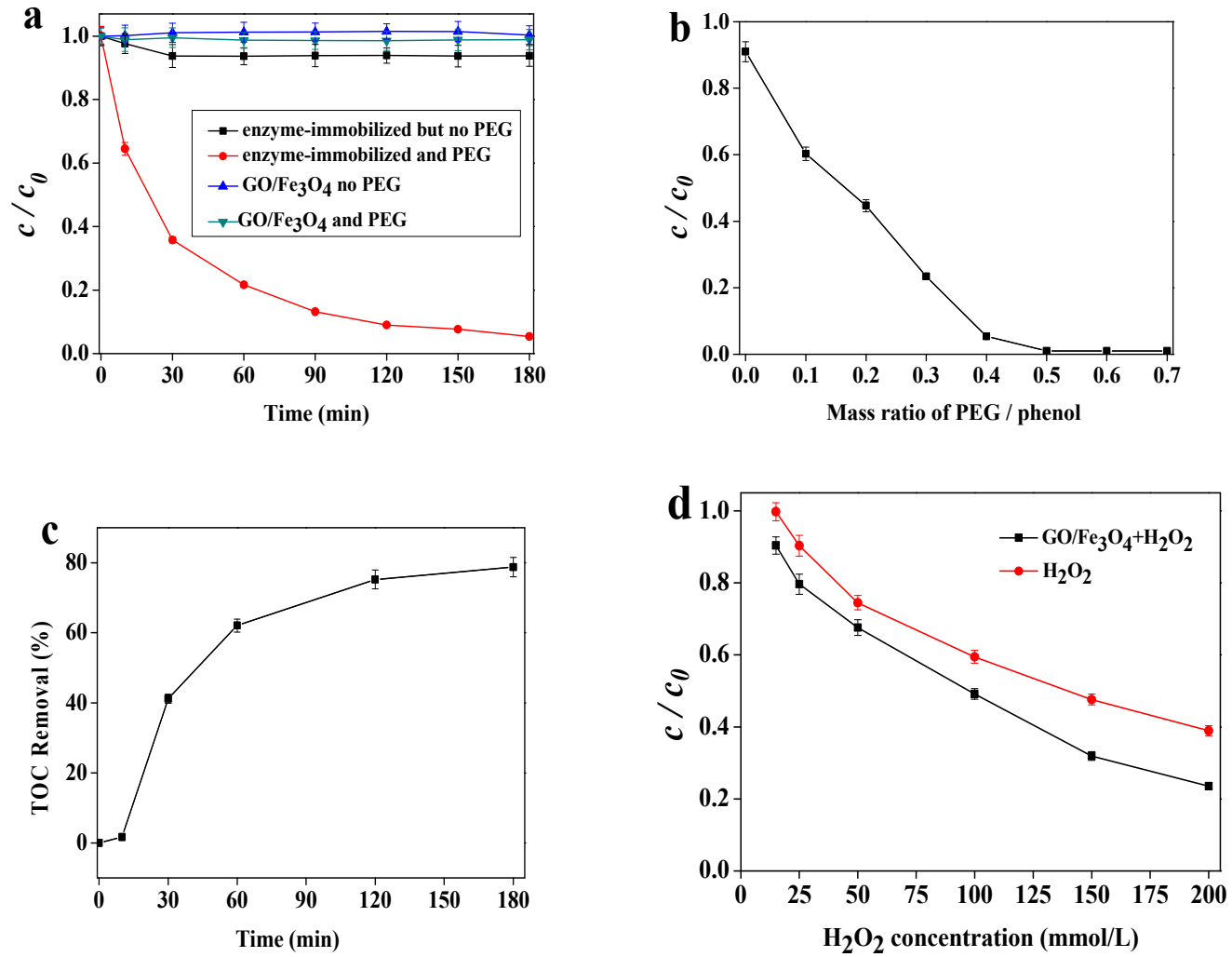

Figure 2. (a) The removals of phenol in different systems; (b) Effect of mass ratio of PEG/phenol dose on phenol removal; (c) The time dependence of removal TOC; (d) Effect of $\mathrm{H}_{2} \mathrm{O}_{2}$ concentration on phenol removal in $\mathrm{Fe}_{3} \mathrm{O}_{4} / \mathrm{GO}$ system without HRP.

As shown in Figure $2 b$, before the mass ratio of PEG/phenol reaches 0.4 , they are significantly enhanced with the increase of the amount of PEG added. The further addition of PEG would result in slightly reduction of the phenol removal efficiency, which was in agreement with the result reported by Cheng et al. [25]. Moreover, the phenol removal efficiency was over $95 \%$ at this time. Both GO and $\mathrm{Fe}_{3} \mathrm{O}_{4}$ possess intrinsic peroxidase-like activity, and we studied the activity of the $\mathrm{GO} / \mathrm{Fe}_{3} \mathrm{O}_{4}$. The concentration of $\mathrm{H}_{2} \mathrm{O}_{2}$ changed when there is only $\mathrm{GO} / \mathrm{Fe}_{3} \mathrm{O}_{4}$. As the amount of $\mathrm{H}_{2} \mathrm{O}_{2}$ is increased, 
the phenol removal grows in quantity (Figure $2 \mathrm{~d}$ ). It is evident from the Figure $2 \mathrm{~d}$ that about $76 \%$ of the phenol is found to be removed because of the $\mathrm{GO} / \mathrm{Fe}_{3} \mathrm{O}_{4}$ catalyzed reaction.

\subsection{Effect of the Immobilized Enzyme Dose}

The catalyst effect of the immobilized enzyme dose is studied, as shown in Figure 3. As the amount of the immobilized enzyme is increased, the phenol removal is significantly promoted until the concentration is about $90 \mathrm{mg} / \mathrm{L}$. The increase of the phenol removal slowed when the dose of immobilized enzyme is higher than $90 \mathrm{mg} / \mathrm{L}$. With HRP concentration increase, more inert intermediate product, phenoxyl radicals, which increase the inactivation chance, will be produced. Therefore, the load of immobilized enzyme was optimized at $90 \mathrm{mg} / \mathrm{L}$.

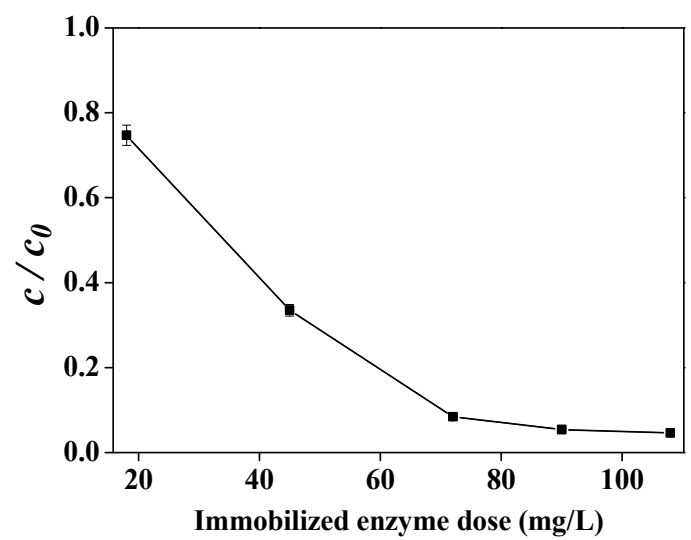

Figure 3. Effect of immobilized HRP dose on phenol removal.

\subsection{Effect of $\mathrm{H}_{2} \mathrm{O}_{2}$ Concentration}

According to the experimental results in the Figure 4, a conclusion can be made that there is a relationship between total phenols removed and a function of $\mathrm{H}_{2} \mathrm{O}_{2}$ provided during the experiment when the molar ratio of $\mathrm{H}_{2} \mathrm{O}_{2}$ to phenol is 1.5, regardless of PEG, which is the optimal conditions in this experiment. Some others reported that the optimum molar ratio of $\mathrm{H}_{2} \mathrm{O}_{2}$ to phenol was 1.0 or 2.0, which might result from polymers larger than dimmers being produced during the catalytic process [26,27]. Enzymes can be inactivated by too much hydrogen peroxide.

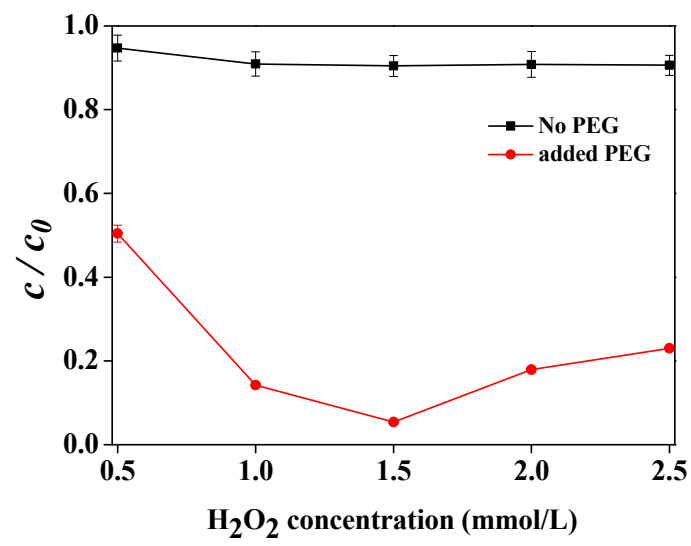

Figure 4. Effect of $\mathrm{H}_{2} \mathrm{O}_{2}$ concentration on phenol removal in the absence and presence of PEG.

\subsection{Degradation of Phenol and 2,4-Dichlorophenol in the Mixture}

As shown in Figure 5a, 2,4-dichlorophenol has almost been completely removed totally, but 30\% of phenol remains. When phenol and 2,4-dichlorophenol are mixed, about $94 \%$ of the phenol was found 
to be removed, similar to the amount previously reported [28], which mean that the easily removed compound (2,4-dichlorophenol) can facilitate the removal of the hard one (phenol). This phenomenon is probably due to the different phenoxy radicals produced by the enzyme. The radicals produced from easy-to-remove phenols can react with the hard-to-remove ones. Therefore, phenol can be removed more easily in presence of 2,4-dichlorophenol than individual one.
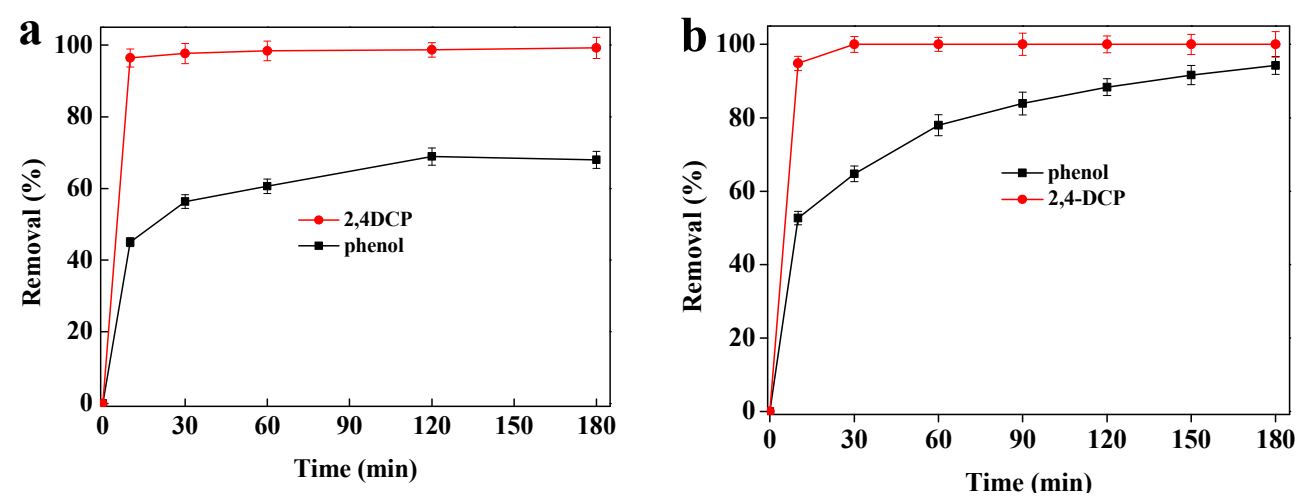

Figure 5. Time profiles of the removals of phenol and 2,4-DCP during the oxidation of: (a) phenol and 2,4-DCP alone; and (b) their mixture.

\subsection{Reusability}

In practical application one attractive advantage of the immobilized enzyme is that it can be easily separated from the reaction system and reused, which greatly decreases the cost of the enzyme. The efficiency of phenol removal reduced with the cycle of the immobilized enzyme as shown in Figure 6. After the first cycle of the catalytic reaction with the HRP immobilized on $\mathrm{GO} / \mathrm{Fe}_{3} \mathrm{O}_{4}$, the timmobilized enzyme was recovered by centrifuging in order to remove the supernatant, and the immobilized HRP was repeatedly washed with double distilled water and the activity was assayed again. After four cycles, enzyme activity dropped to $40 \%$ of its initial activity. The reusability of the immobilized enzyme is dependent on solid support. The activity decline of the immobilized $\mathrm{HRP}$ on $\mathrm{GO} / \mathrm{Fe}_{3} \mathrm{O}_{4}$ can probably be attributed to the polymers produced during the enzymatic reaction, which may cover the enzyme and affect the reaction of the next cycle. Further investigations on improvement of reusability and application of the immobilized enzyme in a continuous-flow device are in process.

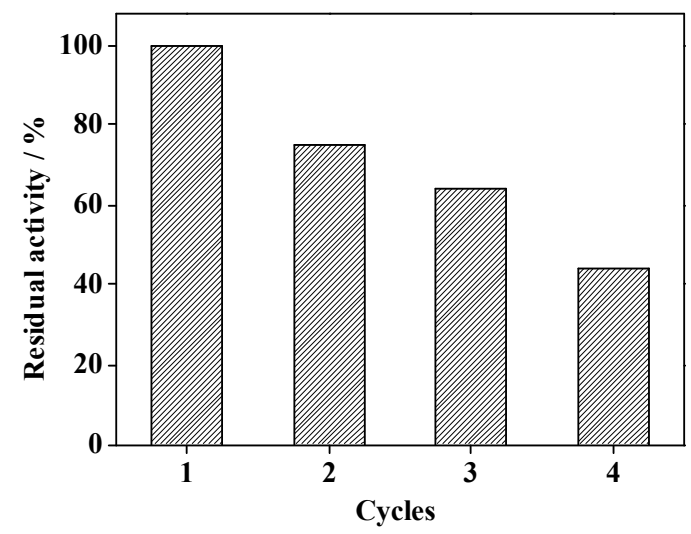

Figure 6. Reusability of the immobilized enzyme in phenol removal. 


\section{Experimental Section}

\subsection{Reagents and Materials}

HRP was purchased from Tianyuan Biologic Engineering Corp. (Wuhan, China) and stored at $-20{ }^{\circ} \mathrm{C} . \mathrm{FeCl}_{3} \cdot 6 \mathrm{H}_{2} \mathrm{O}, \mathrm{FeSO}_{4} \cdot 7 \mathrm{H}_{2} \mathrm{O}, \mathrm{NH}_{3} \cdot \mathrm{H}_{2} \mathrm{O}, \mathrm{H}_{2} \mathrm{O}_{2}(30 \%, w / w)$, phenol, 2,4-DCP, EDC, PEG, $\mathrm{NaH}_{2} \mathrm{PO}_{4} \cdot 2 \mathrm{H}_{2} \mathrm{O}, \mathrm{Na}_{2} \mathrm{HPO}_{4} \cdot 12 \mathrm{H}_{2} \mathrm{O}$, potassium ferricyanide and 4-aminoantipine (4-AAP) were purchased from Sinopharm Chemical Reagent Co, Ltd. (Shanghai, China). All the chemical reagents were of analytical grade and used without further purification. The water used was double distilled water.

\subsection{Preparation of $\mathrm{GO} / \mathrm{Fe}_{3} \mathrm{O}_{4}$ Nanoparticles}

Oxidized graphite was prepared from graphite powder through a modified Hummers method [29]. The $\mathrm{GO} / \mathrm{Fe}_{3} \mathrm{O}_{4}$ nanoparticles were synthesized with an ultrasonic-assisted reverse co-precipitation method [30]. In a typical experiment, $0.2 \mathrm{~g} \mathrm{GO}$ (water suspension), $\mathrm{FeSO}_{4} \cdot 7 \mathrm{H}_{2} \mathrm{O}(0.48 \mathrm{~g}$ ) and $\mathrm{FeCl}_{3} \cdot 6 \mathrm{H}_{2} \mathrm{O}(0.466 \mathrm{~g})$ were dissolved in $50 \mathrm{~mL}$ of distilled water. The mixed solution was added dropwise into $20 \mathrm{~mL}$ of distilled water in which $3 \mathrm{~mL}$ of ammonia water (30\%) was dissolved. The reaction was carried out at $60^{\circ} \mathrm{C}$ in an ultrasound clean bath operating at $25 \mathrm{kHz}$ with a power of $140 \mathrm{~W}$ (KQ-200KDE, Kunshan, China). After $60 \mathrm{~min}$ for the reaction, the generated black GO/ $\mathrm{Fe}_{3} \mathrm{O}_{4}$ nanoparticles were collected by magnetic separation, washed with water to neutral $\mathrm{pH}$, and then dried under vacuum at $50{ }^{\circ} \mathrm{C}$.

\subsection{Immobilization of $\mathrm{HRP}$ on $\mathrm{GO} / \mathrm{Fe}_{3} \mathrm{O}_{4}$}

The above obtained GO/ $\mathrm{Fe}_{3} \mathrm{O}_{4}(0.2 \mathrm{~g}$ ) was dispersed in $20 \mathrm{~mL}$ of PBS solution (pH 6.0) containing $1 \mathrm{mg}$ HRP. One milliliter of EDC $(25 \mathrm{mg} / \mathrm{L})$ was added into the mixture. The immobilization was carried out with shaking for $12 \mathrm{~h}$ at $25^{\circ} \mathrm{C}$. The nanoparticles were separated and washed with PBS solution and water to remove the free enzyme. The enzyme-immobilized nanoparticles were then redispersed in PBS ( $\mathrm{pH}$ 7.0) solution and stored at $4{ }^{\circ} \mathrm{C}$.

\subsection{Characterization}

UV-visible absorption spectra were recorded on a Cary 50 UV-Vis spectrophotometer (Varian, Palo Alto, CA, USA). The magnetic properties were performed using ADE 4HF vibrating sample magnetometer (Lowell, MA, USA) at $300 \mathrm{~K}$. X-ray diffraction patterns were recorded on an X'Pert PRO $X$-ray diffractometer (PANalytical, Almelo, The Netherlands) with a $\mathrm{Cu}$ Ka radiation source generated at $40 \mathrm{kV}$ and $30 \mathrm{~mA}$.

\subsection{Enzyme Activity Measurements}

The colorimetric procedure was used to determine the activity of enzyme [8], in which phenol, 4-AAP and $\mathrm{H}_{2} \mathrm{O}_{2}$ were used as substrates. A mixture was obtained by adding $0.1 \mathrm{~mL} 0.2 \mathrm{~mol} / \mathrm{L}$ phenol, PBS (pH 7.4), $0.1 \mathrm{~mL} 4.8 \times 10^{-2} \mathrm{~mol} / \mathrm{L} 4-\mathrm{AAP}, 20-100 \mu \mathrm{L}$ solution of free or immobilized HRP and $20 \mu \mathrm{L} 2 \times 10^{-3} \mathrm{~mol} / \mathrm{L} \mathrm{H}_{2} \mathrm{O}_{2}$ into a cuvette. The total volume was adjusted by water to $1.8 \mathrm{~mL}$. The catalytic reaction was monitored by recording the absorbance of its red product at $510 \mathrm{~nm}$. One unit of the activity (U) of HRP was defined as the amount of HRP required to hydrolyze $1 \times 10^{-6} \mathrm{~mol}$ of $\mathrm{H}_{2} \mathrm{O}_{2}$ converted per minute under the conditions stated above.

\subsection{Experiments for Removing Phenol and the Mixture of Phenol and 2,4-Dichlorophenol}

The experiment for removing phenol was carried out in $100 \mathrm{~mL}$ conical flasks in a temperature-controlled water bath shaker (SHZ-82A) at temperature of $25^{\circ} \mathrm{C}$ and a constant shaking speed of $160 \mathrm{rpm}$. The typical concentration in the reaction solution $(\mathrm{pH} 7.4)$ contained phenol (1 mmol/L), immobilized enzyme (90 mg/L), PBS (25 mmol/L) and PEG (the mass ratio of PEG/phenol 
was set at 0.4). After $15 \mathrm{~min}$, to achieve of adsorption-desorption equilibrium of phenol on the $\mathrm{GO} / \mathrm{Fe}_{3} \mathrm{O}_{4}$ particles, the degradation was initiated by rapid adding $\mathrm{H}_{2} \mathrm{O}_{2}(1.5 \mathrm{mmol} / \mathrm{L})$ to the reaction solution, the total volume was rapidly adjusted to $40 \mathrm{~mL}$ with distilled water. At given time intervals, $2 \mathrm{~mL}$ aliquots of the reaction solution were sampled, and immediately centrifuged at 14,000 rpm for 3 min with an EBA-21 centrifugal (Hettich, Germany) to remove any sediment.

The experiment for removing the mixture of phenol and 2,4-dichlorophenol was carried out under almost the same conditions as described for removing the mixture of phenol. The difference was that a mixture of phenol $(0.5 \mathrm{mmol} / \mathrm{L})$ and 2,4 -dichlorophenol $(0.5 \mathrm{mmol} / \mathrm{L})$ was used instead of phenol alone, and the load of PEG was $42 \mathrm{mg} / \mathrm{L}$. Each run of the experiments was replicated at least three times.

The detection of the concentrations of phenol and 2,4-dichlorophenol were conducted on high performance liquid chromatography (U-3000 HPLC, Thermo scientific, Waltham, MA, USA) equipped with a C-18 column $(5 \mu \mathrm{m}, 150 \times 4 \mathrm{~mm})$. The mobile phase was methanol/water $(60 / 40)$ at a flow rate of $0.8 \mathrm{~mL} / \mathrm{min}$ and detection wavelength was $270 \mathrm{~nm}$ for phenol and $288 \mathrm{~nm}$ for 2,4-dichlorophenol. Total organic carbon was measured by a TOC (Vario TOC SELECT, Elementar, Hanau, Germany).

\section{Conclusions}

In this study, $\mathrm{GO} / \mathrm{Fe}_{3} \mathrm{O}_{4}$ nanoparticles were synthesized by an ultrasonic-assisted reverse co-precipitation method that was fast and simple, compared with others reported. HRP was successfully immobilized on the $\mathrm{GO} / \mathrm{Fe}_{3} \mathrm{O}_{4}$ via interaction between functional groups of $\mathrm{GO} / \mathrm{Fe}_{3} \mathrm{O}_{4}$ and HRP with EDC. We investigated the catalytic property in phenolic compound removal. Compared with soluble HRP, HRP immobilized on $\mathrm{GO} / \mathrm{Fe}_{3} \mathrm{O}_{4}$ exhibited better thermal stability. PEG improved the enzymatic treatment efficiency of synthetic wastewater significantly. However, the reusability of the immobilized HRP was not satisfactory, possibly because polymers generated during reaction adsorption on the enzyme surface led to enzyme reduction during the reaction cycle. Further investigations on improvement of reusability and application of the immobilized enzyme are in process.

Acknowledgments: This work was supported by the National Science Foundation of China (Grant Nos. 21107143, 21177044 and 21377169) the Fundamental Research Funds for the Central Universities, South-Central University for Nationalities (CZY15003) and the National High Technology Research and Development Program of China (863 Program) (Grant No. 2012AA06A304).

Author Contributions: Qing Chang and Heqing Tang planed the study and wrote the manuscript. Jia Huang and Yaobin Ding carried out the experiments. All authors have given approval to the final version of the manuscript.

Conflicts of Interest: The authors declare no conflict of interest.

\section{References}

1. Yang, M.; Huang, Y.; Cao, H.J.; Lin, Y.H.; Li, X.; Li, H.M. Adsorption of phenol from aqueous solutions using a hydrophilic acrylic ester resin. Environ. Eng. Sci. 2015, 32, 881-890. [CrossRef]

2. Zhou, L.C.; Meng, X.G.; Fu, J.W.; Yang, Y.C.; Yang, P.; Mi, C. Highly efficient adsorption of chlorophenols onto chemically modified chitosan. Appl. Surf. Sci. 2014, 292, 735-741. [CrossRef]

3. Chen, Z.; Li, H.; Gao, Y.Z.; Peng, A.P. Removal of phenanthrene and acenaphthene from aqueous solution by enzyme-catalyzed phenol coupling reaction. Chem. Eng. J. 2015, 265, 27-33. [CrossRef]

4. Nanayakkara, S.; Zhao, Z.Y.; Patti, A.F.; He, L.Z.; Saito, K. Immobilized horseradish peroxidase (I-HRP) as biocatalyst for oxidative polymerization of 2,6-dimethylphenol. ACS Sustain. Chem. Eng. 2014, 2, 1947-1950. [CrossRef]

5. Dong, S.P.; Mao, L.; Luo, S.Q.; Zhou, L.; Feng, Y.P.; Gao, S.X. Comparison of lignin peroxidase and horseradish peroxidase for catalyzing the removal of nonylphenol from water. Environ. Sci. Pollut. Res. 2014, 21, 2358-2366. [CrossRef] [PubMed]

6. Zhang, J.L.; Zhang, F.; Yang, H.J.; Huang, X.L.; Liu, H.; Zhang, J.Y.; Guo, S.W. Graphene oxide as a matrix for enzyme immobilization. Langmuir 2010, 26, 6083-6085. [CrossRef] [PubMed] 
7. Huang, Q.; Huang, Q.G.; Pinto, R.A.; Griebenow, K.; Stenner, R.S.; Weber, W.J. Inactivation of horseradish peroxidase by phenoxyl radical attack. J. Am. Chem. Soc. 2005, 127, 1431-1437. [CrossRef] [PubMed]

8. Nicell, J.A.; Saadi, K.W.; Buchanan, I.D. Phenol polymerization and precipitation by horseradish peroxidase enzyme and an additive. Bioresour. Technol. 1995, 54, 5-16. [CrossRef]

9. Rodrigues, R.C.; Ortiz, C.; Berenguer-Murcia, Á.; Torres, R.; Fernández-Lafuente, R. Modifying enzyme activity and selectivity by immobilization. Chem. Soc. Rev. 2013, 42, 6290-6307. [CrossRef] [PubMed]

10. Garcia-Galan, C.; Berenguer-Murcia, Á.; Fernandez-Lafuente, R.; Rodrigues, R.C. Potential of different enzyme immobilization strategies to improve enzyme performance. Adv. Synth. Catal. 2011, 353, 2885-2904. [CrossRef]

11. Mateo, C.; Palomo, J.M.; Fuentes, M.; Betancor, L.; Grazu, V.; López-Gallego, F.; Pessela, B.C.C.; Hidalgo, A.; Fernández-Lorente, G.; Fernández-Lafuente, R.; et al. Glyoxyl agarose: A fully inert and hydrophilic support for immobilization and high stabilization of proteins. Enzyme Microb. Technol. 2006, 39, 274-280. [CrossRef]

12. Mateo, C.; Palomo, J.M.; Fernandez-Lorente, G.; Guisan, J.M.; Fernandez-Lafuente, R. Improvement of enzyme activity, stability and selectivity via immobilization techniques. Enzyme Microb. Technol. 2007, 40, 1451-1463. [CrossRef]

13. Sheldon, R.A.; van Pelt, S. Enzyme immobilisation in biocatalysis: Why, what and how. Chem. Soc. Rev. 2013, 42, 6223-6235. [CrossRef] [PubMed]

14. Guzik, U.; Hupert-Kocurek, K.; Wojcieszyńska, D. Immobilization as a strategy for improving enzyme properties-application to oxidoreductases. Molecules 2014, 19, 8995-9018. [CrossRef] [PubMed]

15. Gusan, J.M.; Alvaro, G.; Fernandez-Lafuente, R. Industrial design of enzymic processes catalysed by very active immobilized derivatives: Utilization of diffusional limitations (gradients of $\mathrm{pH}$ ) as a profitable tool in enzyme engineering. Biotechnol. Appl. Biochem. 1994, 20, 357-369.

16. Chang, Q.; Tang, H.Q. Immobilization of horseradish peroxidase on $\mathrm{NH}_{2}$-modified magnetic $\mathrm{Fe}_{3} \mathrm{O}_{4} / \mathrm{SiO}_{2}$ particles and its application in removal of 2,4-dichlorophenol. Molecules 2014, 19, 15768-15782. [CrossRef] [PubMed]

17. Garlet, T.B.; Weber, C.T.; Klaic, R.; Foletto, E.L.; Jahn, S.L.; Mazutti, M.A.; Kuhn, R.C. Carbon nanotubes as supports for inulinase immobilization. Molecules 2014, 19, 14615-14624. [CrossRef] [PubMed]

18. Zucca, P.; Sanjust, E. Inorganic materials as supports for covalent enzyme immobilization: methods and mechanisms. Molecules 2014, 19, 14139-14194. [CrossRef] [PubMed]

19. Chang, Q.; Deng, K.J.; Zhu, L.H.; Jiang, G.D.; Yu, C.; Tang, H.Q. Determination of hydrogen peroxide with the aid of peroxidase-like $\mathrm{Fe}_{3} \mathrm{O}_{4}$ magnetic nanoparticles as the catalyst. Microchim. Acta 2009, 165, $299-305$. [CrossRef]

20. Wang, M.Q.; Wang, N.; Tang, H.Q.; Cao, M.J.; She, Y.B.; Zhu, L.H. Surface modification of nano-Fe ${ }_{3} \mathrm{O}_{4}$ with EDTA and its use in $\mathrm{H}_{2} \mathrm{O}_{2}$ activation for removing organic pollutants. Catal. Sci. Technol. 2012, 2, 187-194. [CrossRef]

21. Chang, Q.; Tang, H.Q. Optical determination of glucose and hydrogen peroxide using a nanocomposite prepared from glucose oxidase and magnetite nanoparticles immobilized on graphene oxide. Microchim. Acta 2014, 181, 527-534. [CrossRef]

22. Si, Y.C.; Samulski, E.T. Exfoliated graphene separated by platinum nanoparticles. Chem. Mater. 2008, 20, 6792-6797. [CrossRef]

23. Bai, L.Z.; Zhao, D.L.; Xu, Y.; Zhang, J.M.; Gao, Y.L.; Zhao, L.Y.; Tang, J.T. Inductive heating property of graphene oxide- $\mathrm{Fe}_{3} \mathrm{O}_{4}$ nanoparticles hybrid in an $\mathrm{AC}$ magnetic field for localized hyperthermia. Mater. Lett. 2012, 68, 399-401. [CrossRef]

24. Yan, H.; Zhang, J.; You, C.; Song, Z.; Yu, B.; Shen, Y. Influences of different synthesis conditions on properties of $\mathrm{Fe}_{3} \mathrm{O}_{4}$ nanoparticles. Mater. Chem. Phys. 2009, 113, 46-52. [CrossRef]

25. Cheng, J.; Yu, S.M.; Zuo, P. Horseradish peroxidase immobilized on aluminum-pillared interlayered clay for the catalytic oxidation of phenolic wastewater. Water Res. 2006, 40, 283-290. [CrossRef] [PubMed]

26. Nicell, J.A.; Bewtra, J.K.; Taylor, K.E.; Biswas, N.; St Pierre, C. Enzyme catalyzed polymerization and precipitation of aromatic compounds from wastewater. Water Sci. Technol. 1992, 25, 157-164.

27. Liu, J.Z.; Song, H.Y.; Weng, L.P.; Ji, L.N. Increased thermostability and phenol removal efficiency by chemical modified horseradish peroxidase. J. Mol. Catal. B Enzym. 2002, 18, 225-232. [CrossRef]

28. Entezaria, M.H.; Petrier, C. A combination of ultrasound and oxidative enzyme: Sono-enzyme degradation of phenols in a mixture. Ultrason. Sonochem. 2005, 12, 283-288. [CrossRef] [PubMed] 
29. Chen, C.M.; Yang, Q.H.; Yang, Y.G.; Lv, W.; Wen, Y.F.; Hou, P.X.; Wang, M.Z.; Cheng, H.M. Self-assembled free-standing graphite oxide membrane. Adv. Mater. 2009, 21, 3007-3011. [CrossRef]

30. Wang, N.; Zhu, L.; Wang, D.; Wang, M.; Lin, Z.; Tang, H. Sono-assisted preparation of highly-efficient peroxidase-like $\mathrm{Fe}_{3} \mathrm{O}_{4}$ magnetic nanoparticles for catalytic removal of organic pollutants with $\mathrm{H}_{2} \mathrm{O}_{2}$. Ultrason. Sonochem. 2010, 17, 526-533. [CrossRef] [PubMed]

Sample Availability: Samples of the compounds $\mathrm{Fe}_{3} \mathrm{O}_{4}$ are available from the authors.

(C) 2016 by the authors; licensee MDPI, Basel, Switzerland. This article is an open access article distributed under the terms and conditions of the Creative Commons Attribution (CC-BY) license (http://creativecommons.org/licenses/by/4.0/). 